\title{
The Soft Power of a Small State: Discursive Constructions and Institutional Practices of Norway's Peace Engagement
}

Kristian Stokke

\begin{abstract}
Since the end of the Cold War, Norway has widely functioned as facilitator for conflict resolution in interstate conflicts and, thus, constructed Norwegian foreign policy as an international peace promoter. This article provides a critical understanding of the discursive construction and institutional practices of Norwegian peace engagement and the effectiveness of the Norwegian approach in conflict resolution experiences. By utilising valuable insights from international relations theories, this article critically analyses the construction of identity and interests in Norwegian foreign policy discourse, focusing particularly on the balancing act between realist and idealist internationalism in peace engagement.
\end{abstract}

\section{Introduction}

Why does a small country like Norway take on the role of peace facilitator in distant intrastate conflicts where it has no immediate self-interest, and what characterises and determines the choice of strategy in such peace engagement? Norwegian foreign policy has in recent years been marked by discourses and practices that construct Norway as an international peace promoter. Norway has functioned as facilitator for conflict resolution processes in several intrastate conflicts since the end of the Cold War, supplementing pre-existing roles as peacekeeper under United Nations (UN) leadership and donor of humanitarian and development aid. This new role as peace facilitator was given much publicity with the Israel-Palestine peace process in the early 1990s and has been furthered in other conflict situations since then, including in Colombia, Guatemala, the Philippines, and Sri Lanka. Norway has 
also been involved in internationalised peace-building efforts in Sudan, Timor Leste, Haiti, Ethiopia, Nepal, and other countries. While the initial success of the Israel-Palestine peace process created optimism about Norwegian peace facilitation, the lack of substantive conflict resolution has raised critical questions about Norway's approach and capability (Said, 2001; Waage, 2004). ${ }^{1}$ One decade after the Oslo process, Norway came under strong criticism in Sri Lanka, where Sinhalese nationalists argued that Norwegian peace facilitation was driven by economic interests in the island, constituted neo-imperialist interference in Sri Lankan sovereignty and was systematically biased in favour of the Tamil minority and insurgency. Against this background, the present article provides a critical analysis of the discursive construction and institutional practices of Norwegian peace engagement before examining how the Norwegian approach affected the dynamics and outcome of the Sri Lankan peace process. ${ }^{2}$

The puzzle that motivates this article is that Norway's peace engagement in distant intrastate conflicts cannot be explained with reference to economic or security interests in the conflict zones. While Norway is thoroughly embedded in global relations and has economic interests far beyond its territorial borders, it is difficult to identify Norwegian strategic interests in places such as Colombia, Sri Lanka and the Philippines. This does not mean, however, that Norwegian peace engagement is a matter of mere altruism. Peace engagement may also serve Norwegian economic and security interests by reducing long-distance impacts of intrastate conflicts and grant recognition and influence that support the pursuit of Norwegian interests in international arenas. While it is notoriously difficult to prove the hypothesis that peace engagement supports Norwegian interests internationally, this claim has been made repeatedly and serves as a justification for engagement in distant conflicts (Matlary, 2002). The article, therefore, starts out by examining the construction of identity and interests in Norwegian foreign policy discourse, emphasising the balancing act between realist and idealist internationalism and how peace engagement has provided an opportunity for merging interests and ideals after the end of the Cold War.

Given the discursive construction of Norway as a peace promoter, a key question regards the choice of approach to conflict resolution. This article observes that the characteristics of Norwegian peace engagement depend on context-specific constellations and dynamics, but also display commonalities across the diversity of conflicts. The Norwegian approach to peace engagement, I will argue, revolves around a set of institutionalised practices, including: (1) engagement in peace processes on the basis of invitation and mandate from the protagonists to a conflict; (2) impartial facilitation 
of negotiations based on parity of status between the protagonists; (3) instrumental use of humanitarian and development aid to build peace; (4) close collaboration between the Norwegian state, nongovernmental organisations (NGOs) and like-minded international actors. This approach is based on the realisation that Norway has limited hard power capability in international relations and, thus, must rely on its ability to facilitate dialog between conflicting parties and mobilise international support for negotiated settlements and peace building. The Norwegian approach can, thus, be summarised as 'the soft power of a small nation'. The Sri Lankan case demonstrates that this approach affects the character, dynamics, and outcome of peace processes where Norway plays a facilitator role. The failure of Sri Lanka's peace process in turn raises critical questions about the feasibility of this approach and the future of Norway's peace engagement in a changing global order.

\section{Interest and identity in international relations}

Answering the question of why a small state in northern Europe engages in intrastate conflict resolution in the global South requires attention to its interests and identity. These are pivotal concepts in the study of international relations (IR), where a shift can be observed from a singular emphasis on objective interests to an additional focus on the discursive construction of identities and interests. The formative debates in international relations revolved around the values, interests and strategies of states, and the prospects for international collaboration. Whereas the liberal school holds that peaceful cooperation between states can be built on the basis of universal democratic values and converging interests, the realist school argues that international relations are defined by conflicts of interest between power-seeking states (Burchill et al., 2009).

The contemporary expressions of these schools - neo-realism and neo-liberalism - converge around an understanding of states as strategic and rational actors that operate in a system in which there is no central authority to impose order. These approaches explain the behaviour of states with reference to their economic and security interests and capabilities (Waltz, 1979). Neo-realism and neo-liberalism part ways, however, on the possibility for sustained international cooperation. Whereas neo-realists see states as being preoccupied with their relative standing vis-á-vis other states in a zero-sum game, neo-liberalists hold that states are utilitymaximisers that will enter into cooperation if it yields absolute gains. The high degree of economic and political interdependence in the contemporary world means that states may achieve such absolute gains by collaborating on common concerns that cannot be effectively addressed by individual states. Such collaboration 
includes, for instance, global security, international regulation of trade and finance, and global climate change mitigation (Keohane, 1984). Norway's peace engagement in Sri Lanka has been explained with reference to both perspectives. Whereas Sinhalese nationalists have accused Norway of pursuing economic self-interests in the island, Norwegian diplomats have insisted that Norway has no strategic interests in Sri Lanka and that the facilitator role is motivated by a commitment to international peace and development cooperation. This article seeks to transcend this dichotomy by arguing that Norway's peace engagement is motivated by both ideals and interests, and by arguing that Norway's interests are located elsewhere than in the conflict zone and are pursued indirectly through value diplomacy.

Contemporary studies in international relations are also marked by a debate between the positivist traditions of neo-realism and neo-liberalism, on the one hand, and post-positivist traditions of constructivism and poststructuralism, on the other (Burchill et.al., 2009). This debate revolves around the constructivists' questioning of the materialist and rationalist assumptions of both neo-realism and neo-liberalism. It is argued that studies of international relations must also examine the ideas and beliefs that inform the actors, and how inter-subjective meaning is constructed. In contrast to neo-realism and neo-liberalism, constructivists do not see interests as objectively defined but rather as social constructions. Constructivists acknowledge that actors pursue interests, but there is a need to understand how they define themselves and how this frames their interests. This makes identity the basis for interests and the discursive construction of identities an analytical entry point for understanding interests (Wendt, 1999).

Discourse analysis in international relations examines how socially constructed identities frame foreign policy, making some political strategies seem natural and necessary while excluding others. A discourse constitutes a temporary fixing of meaning built around relatively stable nodal points, but discourses also contain unstable elements where the meaning of signifiers is floating (Sæther, 2008). This implies that discourses are never completely fixed or closed, but always contain spaces for contestation even though there is considerable inertia towards change (Laclau and Mouffe, 2001). Discourses and practices are mutually constitutive in the sense that discourses structure what actors do while, at the same time, are shaped by practices (Foucault 1988, 1995). Discourses construct meaning and define spaces for practice by normalising and legitimising certain kinds of intervention, but discourses may also be altered through alternative practices. The significance of this for this article is that it highlights both that Norwegian foreign policy and diplomatic practices are framed by 
the discursive construction of Norway as a peace promoter, and that the Norwegian peace engagement discourse is based on actual practices of peace facilitation, humanitarian assistance, and development cooperation. This creates a mutually reinforcing logic where it becomes common sense to say that Norway is a peace promoter and to act as a peace facilitator and peace builder. Based on this observation, the following sections will examine Norwegian foreign policy and peace engagement discourse before turning to the institutional practices of peace facilitation with special focus on the Sri Lankan peace process.

\section{Idealism and realism in Norwegian foreign policy}

The recent growth in Norwegian peace engagement must be situated within the discursive construction of Norway's identity and interests in international relations. A recurring theme in Norwegian foreign policy discourse is the central role of geographic factors - especially the small size of Norway - and also its geostrategic location and resource-based economy (Frydenlund, 1982; Leira, 2007; Lunde, Thune, Fleischer, Grünfeld and Sending, 2008; Ministry of Foreign Affairs, 2009; Riste, 2001; Støre, 2008). Riste (2001) observes, on the one hand, that the smallness of the country means that it has little impact on international affairs and limited influence on international conditions that affect its sovereignty and development. On the other hand, he also points to the common argument that the small scale of Norway facilitates a national consensus on foreign policy, and that such consensus is seen as a necessity for a state perceiving itself to be too small and vulnerable to exert substantive power in international relations.

These effects of smallness - a perceived vulnerability in regard to international power relations and a strong emphasis on consensus in foreign policy - have been central to Norwegian foreign policy discourse throughout its short history as a sovereign state. However, as a counter point to this emphasis on smallness, Riste also observes that Norway has at times attained a disproportionate position in certain areas. While Norway undeniably has a small population (less than five million) and a relatively small land area, its extensive maritime economic zone places it among the 15 largest countries in the world (Lunde et.al., 2008). This constitutes the basis for a position of power in certain economic activities such as petroleum, seafood and shipping industries, making Norway one of the richest countries in the world and an important actor in the international energy sector (Rottem, Hønneland et. al., 2008). This resource-based national wealth is also the economic basis for Norway's disproportionally large international engagement in development aid, humanitarian assistance, peace promotion, and 
climate change mitigation, and particularly through its relatively

large contributions to the UN (Østerud, 2006). Thus, Norway can be said to be characterised by the coexistence of a stable identity as a small state and substantial international interests in certain sectors.

This identity - a small state with international interests - has played a key role in forming Norwegian foreign policy. Riste (2001) identifies three key positions in the development of Norwegian foreign policy - neutralism, moralism and internationalism. Each is shaped by the dilemmas associated with the small-state identity. Whereas neutralism is a defensive response to perceived impotence in international politics and an attempt to build an isolationist fence around the country's sovereignty, internationalism is based on the realist recognition that participation in international alliances and arenas is needed in order to ensure its own security and economic interests. Moralism, or what Riste describes as a 'missionary impulse', can be seen as an idealist mode of internationalism operating outside realist security politics and seeking to overcome the small state's lack of power by pursuing influence through value diplomacy. Riste argues that these positions can be traced back to three formative periods in Norway's foreign policy.

Neutralism emerged after Norway gained its independence in 1905 , as a strategy to safeguard both the sovereignty of the new state and the international economic interests of the shipping industry. Moralism gained a prominent position in the inter-war period when Norway engaged itself in idealist promotion of peace, international cooperation, and rule of law, reflecting both the idealist tendencies in international relations at the time and the domestic politics of religious and labour movements (Knutsen, Sørbø and Gjerdåker, 1995; Leira, 2002). Realist internationalism achieved a dominant position during and after World War II, when Norway entered into US-led security alliances and remained a loyal partner throughout the Cold War. Riste (2001) observes that although different periods have been marked by the predominance of one of the three positions, Norwegian foreign policy could be described as an accumulation and coexistence of paradigms. While concerns with neutralism and self-determination have, for example, kept Norway outside the European Union, realist internationalism has led to active participation in North Atlantic security politics (Østerud, 2005). Idealist internationalism has expressed itself as ambivalence towards US-led security politics and through strong commitments to humanitarian and development cooperation, international law, universal human rights, international regulation and support for the UN (Rottem, 2007; Tvedt, 2009). Thus, Norwegian foreign policy has been marked by an uneasy coexistence of realism, idealism and neutralism, producing policies which have been criticised for 
being contradictory and lacking clear goals and strategies. But they have also accommodated different political interests within Norway and, thus, fostered a robust foreign policy consensus (Riste, 2001; Neumann, 2002).

Matlary (2002) and Græger and Leira (2005) observe that these coexisting positions have produced a bifurcation in Norwegian foreign policy between security politics and value diplomacy, in which security interests have been given a clear priority. The relative weight assigned to value diplomacy varies across the left/right axis in Norwegian politics. While security politics has been the foremost concern of the political right, value diplomacy has had a stronger position on the left. However, this left/right division is complicated by the strong legacy of realist internationalism in the Labour Party and the emphasis on value diplomacy within the non-socialist Christian Democratic Party. The division and hierarchical ranking between interests and ideals is also reflected in the traditional institutional division between the Ministry of Foreign Affairs and Ministry of Development Cooperation, with separate government white papers on foreign affairs and development cooperation. Throughout the Cold War period, security was seen as the real interest, with value diplomacy being portrayed as an additional field that was pursued due to a combination of political idealism and economic affluence. Matlary $(2002,2006)$ argues that this has changed after Cold War, when value diplomacy has gained new prominence both internationally and in Norway. The explanation for this is to be found in the changing character of diplomacy due to: the growth of international organisations, agreements, and regulatory regimes; increased importance of international law, rights, and courts; and growing public openness and debate on foreign policy with increased participation by NGOs, media, and others. These changes have increased the need for political legitimacy in international relations, requiring foreign policies and positions to be justified with reference to norms, principles, rights, and agreements rather than solely being based on economic and military command power.

The new centrality of value diplomacy does not necessarily mean that foreign policies are motivated by values, only that diplomatic practices that emphasise ideals and utilise soft power have become more prominent due to the need for political legitimacy. Value diplomacy can therefore be instrumental for the pursuit of security and economic interests. Nye's (2004) work on soft power is especially central to this mode of reasoning. Being concerned about the international standing and potential demise of the US, Nye argues that states may choose to use soft or hard power to affect the behaviour of other actors in order to achieve their own interests. Soft power refers to the power of persuasion as opposed 
to command power based on economic and military resources. Soft power may be pursued independently from economic and military capabilities, but Nye argues that it is most effective if it is combined with hard power. He thus advocates the use of smart power, meaning a strategic combination of the hard power of coercion and payment with the soft power of attraction. Zahran and Ramos (2010) describe this in Gramscian terms as a hegemonic strategy in the sense that soft power is an instrument for normalising domination, or 'coercion armoured by consent'. Others see soft power as a relatively independent source of influence and argue that it is, in fact, most effective when it is delinked from economic and security interests. This is, for instance, the position held by Egeland (1988). He argue that small states like Norway, without vested interests or capability to deploy hard power, could be more effective in facilitating dialog and resolving conflicts through peaceful means.

In this situation, where international diplomacy has shifted, to some extent, from military might to values and rights due to the growth of public diplomacy and need for political legitimacy, Norway has redefined its blend of idealist and realist internationalism. First, Norwegian security politics has undergone major changes (Lange, Pharo and Østerud, 2009; Matlary and Østerud, 2005). Following the collapse of the Soviet Union, Norway faces no immediate threat to its territorial sovereignty, although there are critical concerns regarding the rebuilding of Russia's military capability (Ministry of Foreign Affairs, 2009). Contemporary armed conflicts tend to be intrastate conflicts in the global South rather than the interstate conflicts inscribed in geopolitical rivalry between the US and the Soviet Union of the Cold War period. While there has been increased attention to global security threats from localised new wars (Duffield, 2001; Kaldor, 1999), the Norway's main interests relate to transnational economic activities (especially in oil, seafood and shipping industries), control and management of shared natural resources (especially in the North Atlantic and the Polar regions), and institutional arrangements for global governance including of security, law, and trade (Lunde et al., 2008). At the same time, it can be observed that the North Atlantic Treaty Organisation (NATO), Norway's traditional channel for security politics, now contains a broad diversity of member states with divergent strategic interests, no common existential threat and little attention to geopolitics in the North Atlantic and Arctic, where Norway's territorial interests and leverage are located. In this context, Norway has downsized and re-oriented its armed forces away from territorial defence to participation in UN-sanctioned and NATO-organised international operations, although with a certain reluctance towards out-ofarea military interventions (Græger and Leira, 2005; Matlary and Østerud, 2005; Neumann, 2008; Rottem, 2007). Norway has 
also explored additional Nordic and European arenas for security cooperation and is investing in global regulation through the UN, making Norwegian security contingent on a fourfold security net defined in terms of partly overlapping geographic territories and scales: Nordic, European, North Atlantic and global.

Second, there has also been a growth and thematic shift in value diplomacy. Norwegian engagement politics started from a focus on development and poverty alleviation in the global South, but has seen a growing emphasis on humanitarian assistance and human rights promotion from the late 1980s, peace facilitation and peace building from the early 1990s, and climate change mitigation after the turn of the century (Egeland, 1988; Knutsen, Sørbø and Gjerdåker, 1995; Matlary, 2002; Skånland, 2008; Støre, 2008; Østerud, 2006). This new centrality of engagement politics is also reflected in the institutional arrangements for development cooperation. The former Ministry of Development Cooperation and the Norwegian Agency for Development Cooperation (NORAD) have been integrated into the Ministry of Foreign Affairs, and the Section for Peace and Reconciliation within the Ministry of Foreign Affairs has grown in terms of responsibilities and resources. It can also be noted that international climate change mitigation - the latest addition to Norwegian engagement politics - has become an integral part of foreign policy, and the current Minister for Development Cooperation, Erik Solheim, is also the Minister for the Environment.

Norway's new emphasis on engagement politics, which is facilitated by post-Cold War opportunities in international relations and revolves around development, humanitarian assistance, human rights, peace, and environmental change, is often portrayed as a matter of idealism. However, engagement politics can also be seen as an alternative strategy to acquire influence and benefits in international relations in a situation in which Norway's geostrategic leverage within NATO is lessened, the country remains a nonmember in the European Union, and participation in US-led outof-area operations is politically controversial. Norway is pursuing economic and security interests through diverse arenas, but the access, influence, and benefits from these are varied and depend on Norway's international standing. This gives new centrality to value diplomacy. Hence, Norwegian peace engagement, having initially emerged from Christian and socialist idealist internationalism and in partial opposition to security politics, can be seen as a strategy to obtain recognition and influence in multiple arenas of international relations. It can thus be argued that ideals and interests have merged in the sense that ideals are included in a broadened notion of interests and interests are pursued through the language and practices of idealism (Lunde et al., 2008; Støre, 2008). 


\section{The discursive construction of Norway's peace engagement}

The changing international context for security and value diplomacy is reflected in Norwegian peace engagement discourse. This discourse can be said to have both a short and a long history. Whereas Skånland (2008) points to the emergence and transformation of a distinct peace engagement discourse since the early 1990s, Leira (2002) draws attention to its deep roots in the focus on peace and neutrality in the early history of Norwegian foreign policy (ca. 1890-1940). Although there are links between the old and new peace discourses, these are seldom acknowledged except for occasional remarks about the roots of contemporary peace engagement in the humanitarian 'legacy of Fridtjof Nansen' and Norway's support for the League of Nations in the interwar period (Leira, 2005). The main reason for this disjuncture is the hegemony of realism and security politics throughout the Cold War (Græger and Leira, 2005). As discussed above, this has changed with the transformation of security interests, the growth of transnational economic interests and the increased importance of soft power diplomacy in the post-Cold War period.

Skånland (2008) identifies a distinct Norwegian peace engagement discourse that emerged in the aftermath of the Oslo Accords (Declaration of Principles on Interim Self-Government Arrangements) in the Israel-Palestine peace process in 1993. The most general claim in this discourse is that Norway is an international peace promoter. While this discourse came to the forefront with the Middle East peace process, Skånland shows that there were important ideational precursors in the late 1980s. First, a book by Egeland (1988) entitled Impotent Superpower - Potent Small State has been influential as a conceptual foundation for Norway's current engagement politics. Egeland argues that Norway has advantages and under-utilised potential for humanitarian interventions, human rights advocacy and, by implication, peace promotion. The basis for this claim is to be found in a set of preconditions, most notably: a broad political consensus on foreign policy; few conflicting foreign policy interests; and available funds for foreign assistance. Institutional capabilities are identified as another precondition for successful value diplomacy. Egeland found that this was less developed than the other preconditions at the time of writing, but argued that this could be changed through strategic interventions to build expertise and develop close ties between the state, NGOs and academic institutions. This line of reasoning was later put to practice, not the least by Egeland himself as State Secretary in the Ministry of Foreign Affairs in the formative period of Norway's contemporary peace engagement. Second, Skånland also observes that Government Reports on development assistance and foreign policy in 1987, 1989, and 1992 introduced peace as a goal 
for development cooperation, broadened the concept of security and linked it to global challenges of under-development, and argued that Norway could play a lead role in foreign policy areas where it has expertise and resources (Ministry of Development Cooperation 1987, Ministry of Foreign Affairs 1989, 1992). Nevertheless, peace promotion was yet to be identified as an arena where Norway has comparative advantages and peace was generally treated as a subcategory of humanitarian assistance and democracy promotion. This means that peace was emerging as an important issue, but it was only after the facilitation of the Israel-Palestine peace process that it became a nodal point in Norwegian foreign policy discourse.

Following from the early focus on Norway as a humanitarian superpower, Skånland (2008) observes that the 1990s saw the emergence and consolidation of a Norwegian peace engagement discourse. Starting with the signing of the Oslo Accords in 1993, Norwegian media put much effort into disclosing the details of the Israel-Palestine peace process, relying extensively on accounts from official sources. The overall narrative was about the remarkable success and importance of Norway for the positive outcome of the negotiations. This representation was reaffirmed by reports of international praise for Norwegian peace diplomacy. The message was, in agreement with Egeland's earlier argument, that a small state had achieved what the superpowers had failed to do, namely to resolve a protracted conflict with strong links to international politics. In explaining this success story the media emphasised a set of key factors, especially the close personal contacts and trust that the facilitators managed to build to key actors on both sides of the conflict as well as Norway's neutrality and lack of self-interests. The point was also made that the successful facilitation would yield international recognition that could benefit Norwegian interests, but this did not alter the dominant representation of Norway as a neutral and altruistic peace facilitator. Finally, it was also argued that Norway could repeat its success, utilising the same approach of neutrality, trust, dialog, and facilitation in other conflict situations.

Skånland (2008) shows that these media representations of Norwegian peace engagement were brought into official discourse through speeches by government representatives and government reports on development cooperation (Ministry of Foreign Affairs 1995, 2004). In clear contrast to earlier reports, peace engagement was now a prioritised field in foreign policy. The swiftness with which this shift happened was remarkable. This testifies to the timeliness of the policy change in the context of post-Cold War international diplomacy, the capacity of key actors to make adjustments in Norway's foreign policy and, not the least, the demonstration effect from the Israel-Palestine peace process. Gradually, the basis for peace engagement was broadened across the spectre of political 
parties, with the right-wing Progress Party as the only exception. 148 The facilitator role in the Middle East, the institutionalisation of the peace engagement discourse, and the changes in foreign policy were spearheaded by the Labour Party. ${ }^{3}$ There was some initial contestation from the Conservative Party, which advocated a stronger focus on security interests in the North Atlantic, but this opposition was relatively subdued and short lived. Instead, the Labour Party's interest in peace promotion was furthered by the non-socialist coalition government (1997-2000) led by Prime Minister Kjell Magne Bondevik from the value-oriented Christian Democratic Party. The leader of the Conservative Party, Jan Petersen, who had been a prominent critic of the emphasis on value diplomacy, continued the peace engagement agenda when he held the position as Minister of Foreign Affairs (2001-2005). Thus, it can be observed that six out of the seven parties that are represented in the Norwegian Parliament have participated in government coalitions that have endorsed peace promotion and value diplomacy. ${ }^{4}$ This testifies to the extent in which peace engagement has become an integral part of the foreign policy consensus since the early 1990s.

The rise of the peace engagement discourse has triggered debates about the motivation and results of Norwegian peace engagement. Regarding motivation, the early representations in media, official documents, and speeches emphasised international solidarity and humanitarianism as the basis for Norway's peace engagement. This emphasis on values was challenged in the 1990s by the political right, which argued that idealist peace engagement would shift the focus away from Norway's economic and security interests. The counter argument that emerged held that peace engagement actually benefits those interests. First, engagement politics was said to be beneficial due to the links between distant conflicts and Norwegian economic and security interests. This is the recognition that state and human security in the global South and North are increasingly interconnected in a globalised world (Duffield, 2001; Kaldor, 1999; Støre, 2008). Second, peace engagement was also portrayed as a source of international recognition that could be utilised to promote Norwegian interests in international arenas. This line of reasoning was not the least deployed by the nonsocialist government led by Prime Minister Kjell Magne Bondevik (1997-2000), Foreign Minister Knut Vollebæk and his State Secretary Janne Haaland Matlary, all representing the Christian Democratic Party. Matlary's argument in her roles as politician and academic was that value-based foreign policy gives international political capital that could be instrumental in pursuing economic and security interests, although the conversion from recognition to influence may vary according to issues and arenas of international diplomacy (Matlary, 2002). The new consensus that emerged holds 
that Norwegian peace engagement is motivated by both idealism and realism, with no major conflict between them. Ideals and interests are thus said to go hand in hand in Norway's contemporary foreign policy (Liland and Kjerland, 2003; Støre, 2008). ${ }^{5}$

The past decade has, in particular, witnessed a discussion about the characteristics and effectiveness of Norway's approach to peace. The dominant representation holds that Norway has specific advantages as a small state without a colonial history and with no vested interests or hard power to pressure parties into externally imposed peace deals. It is also argued that Norway has developed competence and a distinct approach to peace promotion in which the basic building blocks are: invited facilitation of political negotiations rather than interventionist peacemaking; an emphasis on dialog with the protagonists based on parity of status and the principle of third-party impartiality; instrumental, flexible, and long-term use of humanitarian and development aid to facilitate conflict resolution and peace building, and; implementation of humanitarian rehabilitation and development for peace building through partnerships between state authorities, non-governmental organisations and multilateral aid agencies. ${ }^{6}$ In the absence of military command power, the Norwegian approach relies on soft power, state economic resources, and network forms of governance to facilitate dialog between the protagonists to a conflict. Höglund and Svensson (2011) describe this as a peace ownership approach because it assigns prime responsibility to the protagonists while placing Norway in a role as facilitating third party with limited power, no immediate self-interest in the conflict, no pre-defined roadmap for the process, or blueprint, for the peace accord. Nevertheless, this approach has a structuring effect on peace processes that involve Norway as a facilitator.

Failure to deliver lasting peace challenges the discursive construction and international standing of Norway as a peace promoter. The critique of Norwegian peace engagement holds that its idealist intentions are not matched by achievements in terms of lasting peace. Whereas defenders of the approach emphasise that Norway can only facilitate and not impose peace, critics assert that the failure to resolve the conflicts in Israel-Palestine and in Sri Lanka indicates that there are fundamental weaknesses in the Norwegian approach. These failures might also undermine the political legitimacy of Norway in international relations, making peace engagement a liability rather than a source of international political capital. Sri Lanka's peace process provides illustrative evidence of the structuring effect of the Norwegian approach and an opportunity to examine the effectiveness of this soft power strategy to conflict resolution. 


\section{Sri Lanka as a test for the Norwegian approach}

The past decade witnessed the emergence of Sri Lanka as a test for ending conflict by political or military means, and for international engagement in relation to both modes of conflict resolution. The last attempt at negotiating an end to the protracted conflict between the Government of Sri Lanka (GOSL) and the Liberation Tigers of Tamil Eelam (LTTE) was characterised by active involvement by a range of international actors as facilitators, donors, and monitors of liberal peace, with Norway as a prominent actor in all three roles. From being an intrastate conflict that was of little relevance beyond the South Asian sub-continent, Sri Lanka became a test for the Norwegian soft power approach to peace facilitation and also, more broadly, for liberal peace building by the US-led 'international community' (Goodhand and Klem, 2005; Liyanage, 2008; Lunstead, 2007; Stokke and Uyangoda, 2011).

Sri Lanka was for 26 years - from July 1983 to May 2009 marked by a protracted intrastate conflict between the Sinhalesedominated ethnocratic state and a militant Tamil nationalist movement demanding self-determination for the Tamil nation and homeland (Tamil Eelam) in north-east Sri Lanka. Tamil nationalism originated in the institutionalisation of ethnic identities and division of labour under British colonial rule and the demands for communal political representation in the transition to independence. It took the form of a non-violent and democratic movement for federalism after independence in 1948, but was radicalised in the 1970s through a separatist movement which, from the 1980s, came to be dominated by militant organisations (Balasingham, 2004; Manogaran and Pfaffenberger, 1994; Wilson, 2000). This militant separatist movement consisted initially of five major organisations, but internal clashes in the late 1980s left LTTE in a dominant position and claiming to be the 'sole representative' of the Tamil nation (Hellmann-Rajanayagam, 1994; Swamy, 1994). ${ }^{7}$

Sri Lanka's intrastate conflict was interspersed by five attempts at political conflict resolution: the Thimpu Talks between the GOSL and the major separatist organisations in 1985; the Indo-Lanka Accord between the GOSL and the Government of India in 1987; the informal talks between President Premadasa's government and LTTE in 1989-1990; the negotiations between the government of President Kumaratunga and LTTE in 1994-1995, and; the peace process between Prime Minister Wickremasinghe's government and LTTE in 2002-2003 (Balasingham, 2004; Gooneratne, 2007; Rupesinghe, 2006; Uyangoda, 2005; Uyangoda and Perera, 2003). Compared to the first four attempts at negotiated conflict resolution, the last peace process was characterised by an extensive internationalisation of the conflict. India had played a key role in the peace processes in the 1980 s, motivated by its 
geopolitical interests in the sub-continent and the complex links between Tamil nationalism in Sri Lanka and domestic politics in India. However, the India refrained from open engagement in the conflict after the failures of the Indo-Lanka Accord and the Indian Peace-Keeping Force (IPKF) in the late 1980s (Muni, 1993). Hence, the Sri Lankan conflict remained a domestic affair largely delinked from international security and development politics (Lunstead, 2007). The last peace process, however, marked a significant change in this respect. Sri Lanka's main aid donors put pressure on the government to seek a political settlement in the late 1990s, when the GOSL suffered military setbacks and faced a severe development crisis. The donors made aid an instrument for peace after the electoral victory of the market-friendly United National Front (UNF) in 2001 and the signing of a ceasefire agreement between GOSL and LTTE in 2002. Funding for peace building was provided or pledged by various donors, especially the co-chairs to the donor conferences (Japan, European Union, the US and Norway). A broad range of international development organisations, including the World Bank, Asian Development Bank, and international NGOs, were involved in humanitarian and development programs, especially after the 2004 Indian Ocean tsunami. It can, therefore, be observed that the question of peace in Sri Lanka became thoroughly internationalised from the late 1990s and that this happened largely through development cooperation (Bastian, 2005, 2007; Burke and Mulakala, 2005; Goodhand and Klem, 2005; Shanmugaratnam and Stokke, 2008; Sriskandarajah, 2003).

This internationalisation of peace by way of development cooperation reflects the changing international discourse on the links between development and peace. During the Cold War, international aid was to a large extent subsumed under the global rivalry between US-dominated capitalism and Soviet-led socialism. Concerns about human rights and democracy were thus downplayed by donors. This changed from the late 1980s when the collapse of the Soviet Union and the triumphalism of western liberalism provided a space for liberal concerns about the efficiency, transparency, and accountability of developmental states. In countries with intrastate conflicts, this shift to good governance also brought new attention to the links between development and peace. In the 1990s, it was increasingly recognised that conflicts pose obstacles to successful development, but also that development could be an instrument for crafting peace (Jarstad and Sisk, 2008; Paris, 2004; Richmond, 2007). Following from this, development cooperation has undergone a general shift from being conflict blind - in the sense that development aid was offered without taking conflicts into consideration - to offering aid in a 
conflict-sensitive manner. This shift also increasingly witnessed the use of development assistance as a tool for transforming conflicts and building liberal peace (Anderson, 1999; Goodhand, 2006). As multilateral aid organisations and donor states became concerned with conflict transformation, political reforms towards peace were added as a precondition for development assistance to countries with intrastate conflicts. Hard power, in the form of aid conditionality, has, therefore, been combined with the soft power of facilitating peace negotiations (Boyce, 2002).

The Sri Lankan conflict in the late 1990s was conducive for this kind of peace promotion. Sri Lanka was characterised by a protracted intrastate conflict that had reached a mutually hurting stalemate and produced a humanitarian and development crisis that made both the GOSL and the LTTE willing to sign the ceasefire agreement, enter into political negotiations, and address humanitarian and developmental needs. At the same time, Sri Lanka's international aid donors were committed to making Sri Lanka a showcase for liberal peace building and found likeminded partners in the UNP-led government and, to some extent, in the network around LTTE's chief negotiator Anton Balasingham (Lunstead, 2007). The Norwegian approach to peace was an acceptable framework to the protagonists while there were no other candidates for the facilitator role that were deemed to be both qualified and politically acceptable. ${ }^{8}$ Thus, domestic and international stakeholders converged around Norway as a capable and impartial facilitator, and the country's approach to peace based on soft power facilitation supported by aid-funded peace building.

Norwegian peace engagement in Sri Lanka originated from the long-standing development cooperation between the two states. Norway-Sri Lanka development cooperation dates back to NGO projects in the late 1960s and bilateral development assistance from the mid 1970s. As Sri Lanka became a middle-income country in the 1990s, Norwegian assistance was increasingly orientated towards peace and reconciliation. Networks, knowledge and trust that originated in development cooperation formed the basis for informal communication between Norway and the protagonists from 1997 to 1999. An agreement was made between the two governments that Norwegian development assistance should support a negotiated solution to the conflict. Following from these precursors, the period from 1999-2002 was marked by the formal invitation and mandate from the GOSL and LTTE to Norway to facilitate peace negotiations and the signing of a ceasefire agreement in 2002. A Sri Lanka Monitoring Mission (SLMM) was established by the Nordic countries to record and coordinate inquiries into ceasefireagreement violations and to support local dispute resolution, although without power to rule on violations or enforce compliance with the ceasefire agreement. 
The period from 2002-2006 was characterised by Norwegian support for capacity building among the protagonists to participate in peace negotiations and six rounds of GOSL-LTTE negotiations in 2002-2003. Negotiations focused primarily on immediate humanitarian and security issues, but also yielded a shared willingness to explore a federal solution to the conflict. After the negotiations stalled in 2003, Norway took various initiatives to restart the stalled peace process - including negotiations to establish a joint mechanism for handling humanitarian assistance after the 2004 Indian Ocean tsunami (McGilvray and Gamburd, 2010). The final period of the GOSL-LTTE conflict, from 2006-2009, was marked by the gradual resumption of armed hostilities and return to full-scale war. Norway's role in Sri Lanka became heavily politicised and public confidence in the facilitator and the peace process plunged. Despite this, the GOSL and the LTTE upheld the formal mandate for Norway as a peace facilitator even after the abrogation of the ceasefire agreement by the GOSL in 2008 (Peiris and Stokke, 2011).

This brief account shows that Norway has, since the late 1990s, sought to facilitate peace in Sri Lanka through the soft power of dialog combined with aid-funded peace building. This facilitator role was backed by the US-led international community and, especially, the co-chairs to Sri Lanka's aid donor conferences. As the peace negotiations stalled, the donors gradually turned to a more hard power strategy whereby aid became conditional on progress towards peace. Assessing Norwegian and international peace engagement in Sri Lanka hence requires close attention to the strength and weaknesses of soft power facilitation in the face of domestic political dynamics and the use of aid as a hard power strategy to restart the stalled peace negotiations.

\section{The soft power of facilitation and the politics of state reforms}

Norway's role in Sri Lanka's peace process exemplifies the Norwegian approach to peace engagement. Höglund and Svensson (2011) observe that the principle of peace ownership permeated the process and determined its key characteristics, including who participated at the negotiation table and which issues were brought up for discussion. Most importantly, the principle of peace ownership placed the responsibility for peace in the hands of GOSL and LTTE, who were defined as the principal parties to the conflict and taken to represent the broader Sinhalese and Tamil communities. The role of Norway was based on invitation, mandate and continued consent from the GOSL and LTTE and was limited to organising communication and negotiations between them. The peace ownership approach, therefore, made the dynamics and outcome of the peace process highly dependent on the positions 
and strategies of the protagonists. Since the GOSL and LTTE's claims to political legitimacy were highly contested, the peace process was also vulnerable to oppositional politicisation on both sides of the ethnic divide. This means that the role of the facilitator was circumscribed by two key conditions: (1) the frozen balance of military power and continued 'war by other means' between the GOSL and LTTE, and; (2) the entrenched institutional and political obstacles to substantive conflict resolution (Stokke, 2011).

First, the peace process was defined by the militarisation of the ethnic conflict and the military balance of power between the GOSL and the LTTE. By the 1990s, the broad diversity of actors and positions within Tamil nationalism had come to be dominated by the military capabilities and strategies of the LTTE. At the same time, the government, led by President Chandrika Bandaranaike Kumaratunga, turned to an all-out 'war for peace' strategy after the failed peace negotiations in 1994-1995. However, the war between LTTE and GOSL reached a mutually hurting stalemate in the late 1990s following a series of military advances by the LTTE that brought extensive areas under their control and created a degree of parity with the GOSL. This power balance brought the protagonists to the negotiation table and kept them from resuming warfare despite the breakdown of the negotiation process, until the balance was altered by uneven military capacity building between the two sides and the changing positions among the international actors in favour of the GOSL. The ceasefire agreement on February 22, 2002, froze this military balance of power, segmented a de facto dual-state structure and institutionalised LTTE and GOSL as the principal parties to the peace process. These constellations were the basis for narrowly defined 'track-one' negotiations focusing primarily on security issues and humanitarian rehabilitation (Uyangoda and Perera, 2003). Other stakeholders were not included in the formal negotiations and there was no additional process aimed at building a political consensus on peace. The political opposition, including the Sri Lankan Freedom Party and the Janatha Vimukthi Peramuna (JVP), the Muslim minority, non-LTTE Tamil actors, and the broad diversity of civil society organisations including the Buddhist Sangha, were all excluded from the peace process. Peace ownership was thus narrowly confined to LTTE and GOSL, based on their military standing in the war and the assumption that they represented the key interests and could negotiate peace for their respective constituencies.

Second, the dynamics and outcome of the peace process were over-determined by domestic political dynamics. Sri Lanka's intrastate conflict was politically produced, and post-independence politics have created entrenched institutional and political obstacles to substantive conflict resolution. The key conflict-producing 
mechanisms were to be found in the way post-colonial liberal democracy fostered ethno-nationalist mobilisation and outbidding, yielding a certain political inclusion of subordinate classes but also Sinhalese majoritarianism, Tamil minority resistance, and constitutional and institutional reforms that furthered majoritarianism (Coomeraswamy, 2003; De Votta, 2004; Stokke, 2011). Uyangoda (2011), therefore, argues that the Sri Lankan state has gained an ethnocratic character that makes state reforms towards accommodating minority grievances exceedingly difficult. Whereas the ethnic mass base of the state undermines pressure from below for state reforms, elite negotiations for peace always run the risk of opportunistic counter-mobilisation. The outcome is an ethnocracy that is conflict producing and with little ability for democratic self-renewal.

Against this background, the peace process was an attempt at elitist crafting of peace amidst entrenched institutional and political obstacles to substantial conflict resolution (Philipson and Thangarajah, 2005; Rampton and Welikala, 2005). The UNP-led government had been brought to power on a political platform that promised peace and development and viewed negotiated peace as a prerequisite for their primary goal of furthering market-led development (Bastian, 2005, 2007). However, the government was based on a weak coalition with a small majority in parliament and faced a fragmented political elite and lack of political consensus on peace. This was especially evident in the contentious cohabitation between the UNP-led government of Prime Minister Ranil Wickremasinghe and the powerful executive President Chandrika Bandaranaike Kumaratunga from the opposition Sri Lanka Freedom Party. The government was also challenged by a broader Sinhalese opposition and its strategies of ethno-nationalist counter-mobilisation and ethnic outbidding.

These political obstacles to peace produced a process that was narrowly defined in terms of the issues that were discussed (Ferdinands et al., 2004). The negotiations were confined to the content and implementation of the ceasefire agreement and the immediate humanitarian needs of war-affected peoples and areas, while the core issues of state reforms towards minority rights, devolution of power, and substantive political representation gained much less attention. In this situation, the GOSL and LTTE sought to pursue their interests and institutionalise their preferred solution as the peace process evolved around other questions than these core issues. The GOSL pursued a strategy of normalising everyday life by way of cessation of hostilities and aid-funded livelihood reconstruction under the assumption that this would depoliticise Tamil grievances and reduce the need for contentious state reforms (Orjuela, 2011). The anticipated peace dividend 
and international aid were also expected to deliver development and political legitimacy for the government within the Sinhalese majority. The LTTE followed a strategy of institutionalising power sharing by building separate state institutions within areas under its control and thereby produce a pretext for internal or external self-determination based on earned sovereignty (Nadarajah and Vimalarajah, 2008; Stokke, 2006, 2007). In this sense, both protagonists used the 'no war/no peace' situation that was created by the ceasefire agreement to pursue their strategic interests, making the peace process an extension of war by other means. This entrenched a de facto dual-state structure, with parallel but very different needs for political transformations within two political entities. On one hand, there was the Sri Lankan state which could be seen as a consolidated electoral democracy characterised by majoritarianism within a unitary and centralised constitution, and various kinds of illiberal political practices (de Votta, 2004). On the other, there was the state-building project within LTTE-controlled areas where LTTE demonstrated an ability to govern but doing so by way of authoritarian centralisation with no mechanisms for democratic representation. These democracy deficits pointed to the need for comprehensive political transformations, but this turned out to be too complicated and contentious to be handled in the peace process (Uyangoda, 2005; Uyangoda and Gomez, 2007). Instead, the talks on state reforms were confined to the question of power sharing between these two units. A noteworthy achievement came in the form of an agreement in 2003 to explore a federal model for Sri Lanka based on the concept of 'internal self-determination' for the Tamils in the north-east (Balasingham, 2004). This indicated that the LTTE was prepared to give up the demand for secession ('external self-determination') and that the GOSL was willing to consider constitutional reforms to accommodate devolution and power sharing. However, the negotiations reached a stalemate in 2003 over the question of interim administration for the north-east, demonstrating the political vulnerability of the peace process.

It can, therefore, be concluded that the Norwegian peace ownership approach made the peace process highly contingent on domestic political constellations. The peace process was especially shaped by the military balance of power between LTTE and GOSL and the political fragmentation and ethnic outbidding within Sinhalese majority politics. These constellations produced a peace process that was narrowly defined both in terms of stakeholders and issues, producing excluded actors and issues that were politicised when the political space for oppositional mobilisation widened. Given the emphasis on peace ownership and soft-power facilitation within the Norwegian approach, it can also be observed that the 
facilitators gave themselves little leverage to ensure inclusivity and substantive progress on core issues amidst entrenched institutional and political constraints.

\section{The hard power of aid and the politicisation of development}

The Norwegian peace ownership approach placed the responsibility for peace in the hands of the LTTE and GOSL in a context where there were entrenched institutional and political obstacles to addressing the core political issues. The pragmatic strategy for peace that emerged from these constellations was one of postponing and depoliticising rather than resolving the core issues of state reforms for power sharing, minority rights, and substantive democratic representation. The main component in this depoliticisation strategy consisted of humanitarian rehabilitation in war-affected areas and normalisation of market-led development throughout the island.

The use of development as a precursor to conflict resolution came out of the crisis of development facing the GOSL and LTTE and international actors at the beginning of the peace process (Kelegama, 2006; Bastian, 2007). The government, on the one hand, was grappling with economic stagnation, soaring military expenses, and rising costs of living that threatened their political legitimacy and electoral survival. The LTTE, on the other hand, faced a humanitarian crisis and a war-weary Tamil population who had suffered massive losses of lives and livelihoods. This situation made development a point of convergence for the warring parties and international actors as it allowed them to pursue their interests through the peace process. 'Peace through development' was certainly acceptable to the UNF government, which had a primary focus on neo-liberal economic development and sought to capitalise on the assumed peace dividend from reduced military expenses and international aid for post-conflict peace building (Bastian, 2007; Orjuela, 2011; Shanmugaratnam and Stokke, 2008). It was also agreeable to the LTTE, which held the position that immediate humanitarian issues should be addressed first, but with the explicit understanding that this would only be the first step toward resolution of the core political issues (Balasingham, 2004). For the international actors, the aim was both to promote the UNF government's market-friendly development model and to make Sri Lanka a success story of liberal peace building (Bastian, 2007; Kelegama, 2006; Lunstead, 2007).

Rainford and Satkunanathan (2011) and Shanmugaratnam and Stokke (2008) observe that this primacy of peace building made development administration a main point of contention between the GOSL and LTTE, as well as a rallying point for the Sinhalese opposition. LTTE viewed an interim administration with 
a fair degree of autonomy and a guaranteed position for the LTTE as an absolute necessity to ensure the fulfillment of both short-term development needs and long-term demands for self-determination. The GOSL, and especially the Sinhalese opposition, feared that an interim administration in the north-east with LTTE in a dominant position would constitute a first step towards secession and hence a substantive threat to the sovereignty of the unitary state. In this situation, the GOSL only proposed minimalist institutional reforms within the framework of the existing constitution. These proposals were rejected by the LTTE on grounds that they were too limited in scope and failed to provide for substantive participation of the LTTE in decision making and delivery of rehabilitation and development in the north-east (Balasingham, 2004). LTTE's counter proposal for an Interim Self-Governing Authority (ISGA) was, however, unacceptable to the GOSL and the Sinhalese opposition because it gave far-reaching powers to the LTTE in the north-east. These disagreements between the protagonists over interim development administration brought the negotiations to a stalemate and, thereby, produced a widening of the political space for the political opposition to mobilise against the peace process. It also produced a pretext for the president to use her constitutional powers to take control of three key ministries, thereby undermining the government and peace process.

In this context, where the negotiations had reached a stalemate and there was mounting opposition against the peace process and the government, the role of the international actors - and especially Norway - was deeply politicised. The shift from progress to stalemate in the negotiations was followed by a shift in the public opinion from support for political negotiations and Norwegian facilitation to growing distrust and critique of the willingness and capability of GOSL, LTTE and Norway to resolve the conflict through peaceful means (Peiris and Stokke, 2011). At the same time, a shift in aid policy among the donors from carrot to stick through the use of aid conditionalities deepened tensions among the donors and between the donors and domestic political actors. These dynamics yielded a growing oppositional mobilisation around the questions of interim administration in the north-east and the donors' aid conditionalities. The discursive nodal point in both cases was the quintessential question of Sri Lanka's territorial integrity and sovereignty.

Norway and the other co-chairs tried to convince the LTTE and the GOSL to restart negotiations after they stalled in 2003. In this they relied, first and foremost, on the soft power of dialog supported by joint statements calling on the protagonists to return to the negotiation table and adhere to the terms of the ceasefire agreement. As this strategy failed to break the stalemate, soft- 
power diplomacy was increasingly supplemented by hard power in the sense that aid became conditional on progress towards peace. Most notably, the donor states and international organisations that attended the Tokyo donor meeting in June 2003 pledged an estimated amount of US\$4.5 billion for the four year period from 2003 to 2006, but explicitly tied this support to a call for progress in the peace process. Thus, the Tokyo Declaration on Reconstruction and Development of Sri Lanka (June 10, 2003) stated more explicitly than what had been done earlier that the donors would monitor the progress towards a set of objectives and milestones:

The international community intends to review and monitor the progress of the peace process closely, with particular reference to objectives and milestones including:

a) Full compliance with the cease-fire agreement by both parties.

b) Effective delivery mechanisms relating to development activity in the North and East.

c) Participation of a Muslim delegation as agreed in the declaration of the fourth session of peace talks in Thailand

d) Parallel progress towards a final political settlement based on the principles of the Oslo Declaration.

e) Solutions for those displaced due to the armed conflict.

f) Effective promotion and protection of the human rights of all people.

g) Effective inclusion of gender equity and equality in the peace building, the conflict transformation and the reconstruction process, emphasizing an equitable representation of women in political fora and at other decision-making levels.

h) Implementation of effective measures in accordance with the UNICEF-supported Action Plan to stop underage recruitment and to facilitate the release of underage recruits and their rehabilitation and reintegration into society.

i) Rehabilitation of former combatants and civilians in the North and East, who have been disabled physically or psychologically due to the armed conflict.

j) Agreement by the Government of Sri Lanka and the LTTE on a phased, balanced, and verifiable de-escalation, demilitarization and normalization process at an appropriate time in the context of arriving at a political settlement. ${ }^{9}$

The donor conference in Tokyo marked a shift in aid policy in the sense that the donors went from using promises of aid as a positive incentive to posing the prospect of reduced support in order to gain leverage and bring the protagonists back to negotiations. 
However, this shift from carrot to stick turned out to be ineffective as it failed to restart the stalled peace process while unavoidably politicising the role of the international actors. Several factors may explain the failure of the peace conditionality, including the flawed implementation by the donors due to their divergent positions on the Sri Lankan conflict and on the use of aid conditionalities. Different interpretations and ambivalence towards the peace conditionality among the donors meant that the protagonists could assume that aid would in any case be forthcoming, thereby reducing the cost of no-compliance. Furthermore, the fact that the conditionalities were imposed rather than negotiated with the protagonists may have reduced their willingness to comply. Mounting opposition from Sinhalese nationalists to the internationalisation of peace, which was portrayed as a neo-imperialist infringement of Sri Lanka's sovereignty, also meant that adherence with the peace conditionality would come at a high political cost for the GOSL (Goodhand and Klem, 2005; Kelegama, 2006; Shanmugaratnam and Stokke, 2008). In fact it seems safe to conclude that the political cost of complying with the peace conditionality would have been higher than the cost of reduced international aid.

These experiences were largely repeated after the 2004 tsunami disaster. Based on the recognition that there were severe institutional and political obstacles to efficient and fair distribution of humanitarian assistance, the international actors urged that a joint mechanism should be established between the GOSL and the LTTE. Norway facilitated a negotiated agreement to establish a Post-Tsunami Operational Management Structure (P-TOMS), but its implementation was paralysed by Sinhalese oppositional mobilization which culminated in a Supreme Court ruling that put P-TOMS on hold on the basis that it could be against the constitution of the unitary state (McGilvray and Gamburd, 2010). Thus, the opportunity created by the tsunami for implementing a joint mechanism for interim development administration and possibly revitalising the peace process was missed.

The Sri Lankan peace process was, therefore, characterised by the use of development as a precursor to peace, but also showed the inherent limitations of this pragmatic strategy. While technocratic collaboration around immediate humanitarian needs was an important trust-building measure, it could not substitute for political conflict resolution. Instead, this strategy politicised development and, especially, the question of interim development administration in the north-east. The subsequent attempt to use aid as a hard-power tool to restart the stalled peace negotiations further politicised development cooperation and the role of international actors, especially Norwegian facilitation. Peiris and Stokke (2011) observe that public support for Norwegian facilitation collapsed 
within both the majority and the minority in the period from 20032005 because negotiations failed to bring peace and the role of Norway became increasingly politicised. The strong public support that Norway enjoyed in 2002-2003 shattered as the peace process stalled and the growing number of ceasefire-agreement violations demonstrated the weaknesses of the SLMM. Both the GOSL and the LTTE criticised foreign monitors for their ineffectiveness and partiality in favour of the other party, while the Sinhalese opposition politicised the role of the donors as neo-imperialism. It was becoming increasingly clear to political actors and the general public that the combination of Norwegian facilitation and domestic military/political constellations had produced a deadlocked 'no war/no peace' situation rather than positive peace. The attempts by donors to break this deadlock through the hard power of payment politicised development cooperation but failed to restart the peace negotiations. While the protagonists were preparing for resumption of war, the international actors came to the realisation that 'money could not buy peace in Sri Lanka'. ${ }^{10}$

\section{The impotence of soft power in the context of 'war on terror'}

Whereas the peace process represented an internationalisation of peace in Sri Lanka that made the Norwegian mode of peace engagement timely and adept, the resumption of warfare and the way it was framed as a 'war on terror' rendered the Norwegian soft power approach impotent and irrelevant. The GOSL's military campaign against LTTE was enabled by changing international relations, especially the US-led war on terror and the growth of Asian powers, resulting in a strong emphasis on state sovereignty and security. This granted international legitimacy and assistance for the state actor and its use of military means against an insurgency organisation labelled as terrorists.

The context for internationalisation of peace in Sri Lanka was shaped by the US-led liberal world order after the end of the Cold War, the associated belief in liberal peace through the global spread of liberal democracy and neo-liberalism, and the liberal internationalism and support for elite-negotiated transitions to peace and democracy during the US presidency of Bill Clinton (1993-2001). Norway's soft-power approach to peace engagement was well adapted to this context of western liberal internationalism, and Sri Lanka was viewed as a potential showcase for liberal peace building after the election of the market-friendly UNP-led government (Lunstead, 2007). However, the assumption that it would be possible to craft peace through internationally facilitated elite negotiations and aid-funded peace building, were complicated and undermined by the contextual politics of state and market 
reforms, as outlined above (Bastian, 2007; Shanmugaratnam, 2008; Stokke, 2009; Stokke and Uyangoda, 2011). When the peace negotiations between the GOSL and the LTTE (2002-2003) stalled and soft-power facilitation and aid conditionalities failed to break the stalemate, both the GOSL and the LTTE turned to the possibility and necessity of resolving the conflict by military means. The regime change in 2005 to the SLFP-led government of President Mahinda Rajapakse marked the change from a liberal peace agenda to an offensive 'war against terrorism', while the assassination of Sri Lanka's Foreign Minister Lakshman Kadirgamar in 2005 was seen as a sign of LTTE's return to military means. Thus, the 'no war/no peace' situation that existed in 2004-2006 was replaced by renewed warfare from 2007 and a final military victory for the GOSL in 2009. This military success was enabled by changing international relations that widened the political space for the GOSL to build both their political legitimacy and military capability.

First, it can be observed that the US-initiated 'war on terror' provided a legitimising framework for labelling, proscribing, and attacking the LTTE as a 'terrorist' organisation (Nadarajah and Sriskandarajah, 2005). Prior to the Al Qaida attack in New York City on September 11, 2001, intrastate conflicts at the periphery of the world order were generally not construed as international security problems. After 9/11, intrastate conflicts were increasingly framed as global security threats due to the possibility of spillover effects through international migration, criminal networks and transnational terrorism (Kaldor, 1999). This representation provides legitimacy to military strategies to combat terrorism, protect state security and impose political order. Nadarajah and Sriskandarajah (2005) observe that the strategy of labelling LTTE as a terrorist organisation has been applied by the GOSL since the late 1970s. This did not necessarily limit the LTTE's military capability but it certainly undermined LTTEs international legitimacy and proclaimed political project of national liberation. At the same time, the authors observe that the politics of naming the LTTE as an terrorist organisation had a legitimising and mobilising effect for the GOSL in domestic politics and internationally:

Deploying the rhetoric of terrorism had three distinct benefits for the Sri Lankan state: it de-legitimised (Tamil) agitation for political independence (with which terrorism has been conflated) thereby enabling the 'securitisation' of the issue; it mobilised Sinhala sympathy for the regime and its actions; and, international criticism of rights notwithstanding, accomplished the same abroad (Nadarajah and Sriskandarajah, 2005: 91). 
The success of this strategy is reflected by the fact that LTTE has been designated as a terrorist organisation by a number of states (including the US, UK, India, Australia and Canada) due to its armed tactics more than it posing a security threat to their national interests. Such terror listing of LTTE did not prevent internationally facilitated peace negotiations with LTTE as the principal representative of Tamil minority grievances or the establishment of diplomatic relations and development cooperation with the organisation during the peace process. However, this interaction remained conditional on the Sri Lankan state's approval. When the GOSL intensified its discursive and military campaign against LTTE from 2005 onwards, the organisation was increasingly handled as a terrorist organisation by the international actors. This framing could be justified with reference to ceasefireagreement violations and continued child recruitment by the LTTE, as well as assassinations of Tamil and Sinhalese adversaries. This situation left Norway in a precarious position with little leverage among the co-chairs and vis-a-vis the GOSL to promote and pursue its political approach to conflict resolution. Norway refrained from labelling or proscribing LTTE as a terrorist organisation as this would violate the impartiality of the facilitator role, but this allowed Sinhalese nationalist to label Norway as pro-LTTE and thereby make it increasingly difficult for Norway to play a facilitating role and, in particular, exert influence on the GOSL.

Second, changing international relations towards a multipolar world order and the emergence of 'new' Asian powers (especially China and India) with economic and geopolitical interests in the Indian Ocean, and an emphasis on state sovereignty and security, created new opportunities for the GOSL to develop its military capability and successfully pursue a war against the LTTE (Centre for Just Peace and Democracy, 2008; Kaplan, 2009). This can be seen as a skilful playing of three geopolitical powers in the region (US, Indian and China) and associated allies (for example, Iran, Pakistan and Israel) to acquire military hardware, training and intelligence, while simultaneously defusing international demands for resumed negotiations and protection of human rights in the context of war. It can also be argued that although these geopolitical stakeholders are strategic competitors in the Indian Ocean, they share a common concern with state sovereignty and security in the face of insurgency movements (Sharma, 2009). Thus, the complex dynamics of strategic competition and converging interests between the US, India, and China provided a space for GOSL to conduct its war against LTTE. Other powers, such as Japan and the European Union, refrained from playing a geopolitical role. However, they continued to offer development assistance to the Sri Lankan state 
while treating LTTE as an illegitimate non-state actor and, therefore, granting de facto support and legitimacy for the GOSL. Occasional joint statements from the co-chairs encouraging the protagonists to return to negotiations and respect human rights and international law did little to alter the overall pattern of international support and legitimacy for the war against LTTE. Most importantly, this meant that the relative parity of status that had existed between GOSL and LTTE during the peace process was replaced by asymmetry in the international actors, who then were dealing with the GOSL and LTTE as state and non-state actors. The international community generally came to accept the deployment of force by a sovereign state against an internationally banned terrorist organisation and refrained from taking strong action against the GOSL on questions of human rights and international law. Thus, the conflict was discursively reframed from being a conflict over minority rights and self-determination that should be resolved through politically negotiated liberal peace, to become a war against terrorism in which defeating LTTE became a prerequisite for state security, rule of law, and peace. In this situation, Norway's soft-power approach was rendered irrelevant and impotent by the military strategies of the warring parties and the dwindling domestic and international support for political conflict resolution. Norway's earlier insistence on parity of status between the two protagonists in the peace process was now replaced by the view that treating LTTE on par with GOSL had been a biased practice that shifted power in favour of the non-state actor.

In this situation, where the facilitator role was formally continued although the parties were engaged in all-out war, Norway focused on maintaining communication with the protagonists, the co-chairs, and India. The facilitator role prevented Norway from exerting substantive pressure on the protagonists despite the harsh realities of the final stage of the war. The co-chairs, which held different views on the conflict, issued occasional joint statements that called on the protagonists to respect international law and return to political negotiations. But they also came to adopt the position that Sri Lanka, as a sovereign state, had a right to protect its security in the face of armed insurgency. Thus, Norway returned to the role of humanitarian aid donor, claiming to operate according to principles of neutrality and impartiality. In the post-war period since May 2009, Norway has, in a similar manner, combined realist recognition of Sri Lanka's sovereignty with critical attention to humanitarian needs, insisting that good diplomatic relations between Norway and Sri Lanka are crucial to gain access and deliver humanitarian assistance to war-affected people and areas. 


\section{Conclusion}

The purpose of this article has been to examine the discursive construction of peace engagement in Norwegian foreign policy and to examine the characteristics and effectiveness of the Norwegian approach to peace. The article has argued that Norwegian peace engagement has emerged in the post-Cold War period as a response to Norway's desire and potential to pursue both values and interests in international relations. US-centred international relations after the Cold War have provided an opportunity for merging interest politics and value diplomacy through multifaceted engagement politics. Norway's engagement in intrastate conflicts, such as the one in Sri Lanka, must be understood within this framework rather than be explained with reference to immediate Norwegian interests in conflict-affected areas. The article has also argued that it is possible to identify a distinct Norwegian peace engagement approach revolving around soft-power facilitation supported by aid-funded peace building and network governance among likeminded actors. The Sri Lankan case illustrates that the Norwegian approach does affect the character, dynamics, and outcomes of Norwegian-facilitated peace processes, but it also shows that it is not only Norway but the US-led international community that is being put to test.

The Sri Lankan peace process draws critical attention to the question of effectiveness: Can Norway's peace engagement deliver lasting peace and does it serve Norwegian interests internationally? First, regarding the question of whether the Norwegian approach works, it can be observed that the Sri Lankan peace process brought out inherent limitations in the Norwegian approach. On the one hand, it can be noted that soft-power facilitation and peace ownership made the dynamics and outcome of the peace process vulnerable to the positions and strategies of the protagonists and the institutional and political obstacles to substantive conflict resolution. The attempt to use development as a tool for depoliticising the conflict and as a source of hard power politicised development and the role of the donors without achieving the desired outcomes. Furthermore, the final phase of the conflict demonstrated the impotence and irrelevance of soft-power facilitation in the context of the domestic and international 'war on terror'. The required impartiality of the facilitator role and the changing international relations in favour of GOSL and state security prevented Norway from exerting substantive influence on the basis of international conventions and laws regarding human rights and conduct of war.

Second, regarding the question of whether peace engagement serves Norwegian interests internationally, it can be argued that failed peace processes like the one in Sri Lanka challenge the international standing of Norwegian peace engagement. However, 
it does not automatically translate into loss of political capital. The accumulation or loss of political capital from peace engagement also depends on how the conduct of Norwegian peace diplomacy is understood and how failures are explained. Furthermore, the extent and manner in which recognition is translated into international influence is complex and may vary from one policy field to another and between different arenas of international relations. This means that it is notoriously difficult to detect and measure the direct benefits from peace engagement. ${ }^{11}$

Finally, the Sri Lankan peace process also raises critical questions about the kind of peace that is sought and the political forces and dynamics that can drive the process towards desired outcomes. The international actors that were involved in the Sri Lankan process did not spell out their conception of peace but nevertheless pursued a liberal peace agenda. Towards this end, they relied on the political mandate and capability of the UNP-led government to deliver sufficient political concessions to depoliticise the conflict and transform the LTTE in a political direction. In retrospect, it can be concluded that this model was undermined by entrenched political dynamics that were furthered, rather than transformed, by the design of the peace process itself (Stokke and Uyangoda, 2011). I have observed elsewhere that political elites who were excluded from important and contentious processes of state reforms and intermediate Sinhalese classes that experienced social exclusion associated with market-led development, united in forceful opposition to the peace process, the government, and the international actors (Stokke, 2011). This political undermining of the peace process highlights the importance of substantive social and political inclusion to ensure sustainable and just peace. Sri Lanka's peace process raises a number of questions about the degree to which internationalised crafting of liberal peace and, in particular, the Norwegian approach to peace can ensure this kind of social and political inclusion. The foremost lesson from Sri Lanka's peace process is, in my view, that there is no short cut through narrowly defined and exclusionary elite negotiations to lasting peace with justice. This observation calls for careful analysis and strategic interventions to identify and further political dynamics that are conducive to positive peace. 


\section{Endnotes}

${ }^{1}$ It should be noted that the criticism that was voiced against Norway in the IsraelPalestine Peace Process was overshadowed in Norwegian media and policy debate by the praise for Oslo process. It is difficult to find evidence that the critique affected Norwegian policy making in regard to the Sri Lankan peace process.

2 The article is informed by my research on politics and development in Sri Lanka since the late 1980s and continuous attention to the politics of the peace process since 2001. It is also based on numerous meetings and conversations with miscellaneous actors and observers in the peace process. No individual sources are identified in the article for political reasons.

3 Three Ministers of Foreign Affairs from the Labour Party gave leadership to peace engagement in this formative period: Thorvald Stoltenberg (1990-1993), Johan Jørgen Holst (1993-1994) and Bjørn Tore Godal (1994-1997). Jan Egeland functioned as State Secretary in the Ministry of Foreign Affairs from 1990 to 1997.

${ }^{4}$ In addition to the legacy of consensus in foreign policy comes the fact that recent governments have had to rely on negotiations and strategic coalitions to mobilise a majority in Parliament. Norway has had five governments since 1990 where only the last one has had more than fifty percent of the seats in Parliament. These governments include a Labour Party government led by Gro Harlem Brundtland (1990-1997), a non-socialist coalition government consisting of the Christian Democratic Party, the Liberal Party and the Centre Party led by Kjell Magne Bondevik (1997-2000), a Labour Party government led by Thorbjørn Jagland (2000-2001), a non-socialist coalition government from the Christian Democratic Party, the Conservative Party and the Liberal Party led by Kjell Magne Bondevik (2001-2005), and a red-green coalition government consisting of the Labour Party, the Socialist Left Party and the Centre Party led by Jens Stoltenberg (since 2005).

${ }^{5}$ This argument has acquired a hegemonic position but is not uncontested. In addition to the realist critique of value diplomacy that was mentioned earlier, there is also an idealist critique of the instrumental use of peace engagement to promote Norway's standing and influence in international arenas. Some critics have especially argued that there is a contradiction between appearance and essence in Norway's peace engagement, as demonstrated by Norway's participation in military operations in Afghanistan.

6 Such neo-corporatist arrangements between the state and civil society in engagement politics is sometimes presented as the core of the 'Norwegian model', emphasising lean bureaucracy and flexible governance networks in policy making and implementation.

7 Eelam People's Revolutionary Liberation Front (EPRLF), Eelam Revolutionary Organisation of Students (EROS), Liberation Tigers of Tamil Eelam (LTTE), People's Liberation Organisation of Tamil Eelam (PLOTE) and Tamil Eelam Liberation Organization (TELO)

${ }^{8}$ The Government of Japan sought a facilitator role in the early stage of the process but this was not acceptable to the LTTE and India. The Government of India followed the conflict closely without being openly involved and the Norwegian facilitators maintained close contact and attained India's support for the peace process.

${ }^{9} \mathrm{http}$ // /www.mofa.go.jp/region/asia-paci/srilanka/conf0306/declaration.html

${ }^{10}$ This is an expression that has been used in several media appearances by Erik Solheim, Norway's special envoy to Sri Lanka's peace process.

${ }^{11}$ The Norwegian Ministry of Foreign Affairs has initiated an international evaluation of Norway's role in Sri Lanka's peace process as a basis for possible reassessment and transformation of the Norwegian approach to peace. This evaluation is scheduled to be completed in mid-2011. 


\section{References}

Anderson, M. B. (1999) Do not Harm. How Aid can Support Peaceor War, Boulder: Lynne Rienner.

Balasingham, A. (2004) War and Peace. Armed Struggle and Peace Efforts of Liberation Tigers, Mitcham, UK: Fairmax.

Bastian, S. (2005) The Economic Agenda and the Peace Process, Colombo: Asia Foundation Sri Lanka Strategic Conflict Assessment.

Bastian, S. (2007) The Politics of Foreign Aid in Sri Lanka. Promoting Markets and Supporting Peace, Colombo, Sri Lanka: International Centre for Ethnic Studies.

Burchill, S., A. Linklater, R. Devetak, J. Donnelly, T. Nardin, M. Paterson, C. Reus-Smit and J. True (2009) Theories of International Relations (4th eds.), New York: Palgrave Macmillan.

Burke, A. and Mulakala, A. (2005) Donors and Peacebuilding, Colombo: The Asia Foundation.

Boyce, J. K. (2002) Investing in Peace: Aid and Conditionality after Civil Wars, Oxford: Oxford University Press.

Centre for Just Peace and Democracy (2008) International Dimensions of the Conflict in Sri Lanka, Emmenbrucke, Switzerland: Centre for Just Peace and Democracy.

Coomeraswamy, R. (2003) 'The Politics of Institutional Design. An Overview of the Case of Sri Lanka', In Sunil Bastian and Robin Luckham (eds.), Can Democracy be Designed? The Politics of Institutional Choice in Conflict-torn Societies, London: Zed Books.

De Votta, N. (2004) Blowback. Linguistic Nationalism, Institutional Decay, and Ethnic Conflict in Sri Lanka, Stanford: Stanford University Press.

Duffield, M. (2001) Global Governance and the New Wars: The Merging of Development and Security, London: Zed.

Egeland, J. (1988) Impotent Superpower - Potent Small State. Potentials and Limitations of Human Rights Objectives in the Foreign Policies of the United States and Norway, Oslo: Norwegian University Press.

Ferdinands, T., Rupesinghe, K. Saravanamuttu, P. Uyangoda, J. and Ropers, N. (2004) The Sri Lankan Peace Process at Crossroads. Lessons, Opportunities and Ideas for Principled Negotiations and Conflict Transformation, Colombo: Centre for Policy Alternatives, Foundation for Co-Existence, Initiative for Political and Conflict Transformation, Social Scientists' Association, Berghof Foundation for Conflict Studies Sri Lanka Office. 
Foucault, M. (1988) Madness and Civilization. A History of Insanity in the Age of Reason, New York: Vintage.

Foucault, M. (1995) Discipline and Punish: The Birth of the Prison, New York: Vintage.

Frydenlund, K. (1982) Lille land - hva nå? Oslo: Norwegian University Press.

Goodhand, J. (2006) Aiding Peace? The Role of NGOs in Armed Conflict. Bourton on Dunsmore, UK: ITDG Publishing.

Goodhand, J. and Klem, B. (2005) Aid, Conflict and Peacebuilding in Sri Lanka, Colombo: The Asia Foundation.

Gooneratne, J. (2007) Negotiating with the Tigers (LTTE), Pannipitiya, Sri Lanka: Stamford Lake.

Græger, N. and Leira, H. (2005) 'Norwegian Strategic Culture after World War II: From a Local to a Global Perspective', Cooperation and Conflict 40(1): 45-67.

Hellmann-Rajanayagam, D. (1994) The Tamil Tigers: Armed Struggle for Identity, Stuttgart: Franz Steinert Verlag.

Höglund, K. and Svensson, I. (2011) 'Fallacies of the Peace Ownership Approach: Exploring Norwegian Mediation in Sri Lanka', In K. Stokke and J. Uyangoda (eds.), Liberal Peace in Question. Politics of State and Market Reforms in Sri Lanka. London: Anthem. Forthcoming.

Jarstad, A. K. and Sisk, T. D. (eds.) (2008) From War to Democracy. Dilemmas of Peacebuilding, Cambridge: Cambridge University Press.

Kaldor, M. (1999) New and Old Wars: Organised Violence in a Global Era, Cambridge: Polity Press.

Kaplan, R. (2009) 'Center Stage for the $21^{\text {st }}$ Century. Power Plays in the Indian Ocean', Foreign Affairs 88, 2.

Kelegama, S. (2006) Development under Stress. Sri Lankan Economy in Transition, New Delhi: Sage.

Keohane, R. (1984) After Hegemony. Cooperation and Discord in the World Political Economy, Princeton: Princeton University Press.

Knutsen, T. L., Sørbø, G. M. and Gjerdåker, S. (1995) Norges utenrikspolitikk, Oslo: Cappelen.

Laclau, E. and Mouffe, C. (2001) Hegemony and Socialist Strategy, London: Verso.

Lange, E., Pharo, H. and Østerud, Ø. (2009) Vendepunkter $i$ norsk utenrikspolitikk: Nye internasjonale vilkår etter den kalde krigen, Oslo: Unipub.

Leira, H. (2002) Internasjonal idealisme og Norge. Utenrikspolitisk tenkning fra Justus Lipsius til Halvdan Koht, Department of Political Science: University of Oslo.

Leira, H. (2005) Folket og freden. Utviklingstrekki norsk fredsdiskurs 1890-2005, Internasional Politikk 63(2-3): 135-160. 
Leira, H. (ed.) (2007) Norske selvbilder og norsk utenrikspolitikk, Oslo: Norwegian Institute of International Affairs.

Liland, F. and Kjerland, K. A. (2003) Norsk utviklingshjelps historie (bind 3). 1989-2002: På bred front, Bergen: Fagbokforlaget.

Liyanage, S. (2008) 'One Step at a Time'. Reflections on the Peace Process in Sri Lanka, Colombo: South Asia Peace Institute.

Lunde, L., Thune, H., Fleischer, E. Grünfeld, L. and Sending, O. J. (2008) Norske interesser: Utenrikspolitikk for en globalisert verden, Oslo: Cappelen Damm.

Lunstead, J. (2007) The United States' Role in Sri Lanka's Peace Process 2002-2006, Colombo: The Asia Foundation.

Manogaran, C. and Pfaffenberger, B. (eds.) (1994) The Sri Lankan Tamils, Ethnicity and identity, Boulder, CO: Westview.

Matlary, J. H. (2002) Verdidiplomati - kilde til makt? En strategisk analyse av norsk utenrikspolitikk, Oslo: Makt- og demokratiutredningen.

Matlary, J. H. (2006) Values and Weapons. From Humanitarian Intervention to Regime Change, Basingstoke: MacmillanPalgrave.

Matlary, J. H. and Østerud, Ø. (eds.) (2005) Mot et aunasjonalisert forsuar, Oslo: Abstrakt.

McGilvray, D. B. and Gamburd, M. R. (eds.) (2010) Tsunami Recovery in Sri Lanka: Ethnic and Regional Dimensions, London: Routledge.

Ministry of Development Cooperation (1987) Report no. 34 to the Storting (1986-87): Om hovedspørsmål i norsk utviklingshjelp, Oslo: Ministry of Development Cooperation.

Ministry of Foreign Affairs (1989) Report no. 11 to the Storting (1989-90): Om utviklingstrekk $i$ det internasjonale samfunn og virkninger for norsk utenrikspolitikk, Oslo: Ministry of Foreign Affairs.

Ministry of Foreign Affairs (1992) Report no. 51 to the Storting (1991-92): Om utviklingstrekki Nord-Sør forholdet og Norges samarbeid med utviklingslandene, Oslo: Ministry of Foreign Affairs.

Ministry of Foreign Affairs (1995) Report no 19 to the Storting (19951996): En verdeni endring. Hovedtrekki norsk politikk overfor utviklingslandene, Oslo: Ministry of Foreign Affairs.

Ministry of Foreign Affairs (2004) Report no 35 to the Storting (2003-2004): Felles kamp mot fattigdom. En helhetlig utviklingspolitikk, Oslo: Ministry of Foreign Affairs.

Ministry of Foreign Affairs (2009) Report no 15 to the Storting (20082009): Interesser, ansvar og muligheter. Hovedlinjer $i$ norsk utenrikspolitikk, Oslo: Ministry of Foreign Affairs.

Muni, S. D. (1993) Pangs of proximity: India and Sri Lanka's ethnic crisis, Oslo: International Peace Research Institute. 
Nadarajah, S. and Vimalarajah, L. (2008) The Politics of Transformation: The LTTE and the 2002-2006 Peace Process in Sri Lanka, Berlin: Berghof Research Center for Constructive Conflict Management.

Nadarajah, S., and Sriskandarajah, D. (2005) Liberation Struggle or Terrorism? The Politics of Naming the LTTE, Third World Quarterly 26 (1): 87-100.

Neumann, I. B. (2002) Norges handlingsrom og behovet for en overgripende sikkerhetspolitisk strategi, Oslo: Den norske atlanterhavskomité.

Neumann, I. B. (ed.) (2008) Norge og alliansene. Gamle tradisjoner, nytt spillerom, Oslo: Norwegian Institute of International Affairs.

Nye, J. S. (2004) Soft Power. The Means to Success in World Politics, New York: Public Affairs.

Orjuela, C. (2011) 'Buying Peace? Politics of Reconstruction and the Peace Dividend Argument', In K. Stokke and J. Uyangoda (eds.), Liberal Peace in Question. Politics of State and Market Reforms in Sri Lanka, London: Anthem. Forthcoming.

Paris, R. (2004) At war's end. Building peace after civil conflict, Cambridge, UK: Cambridge University Press.

Peiris, P. and Stokke, K. (2011) 'Liberal Peace and Public Opinion', In K. Stokke and J. Uyangoda (eds.), Liberal Peace in Question. Politics of State and Market Reforms in Sri Lanka. London: Anthem. Forthcoming.

Philipson, L. and Thangarajah, Y. (2005) The Politics of the NorthEast, Colombo: The Asia Foundation.

Rainford, C. and Satkunanathan, A. (2011) 'From SIHRN to PostWar North and East: The Limits of the Peace through Development Paradigm in Sri Lanka', In K. Stokke and J. Uyangoda (eds.), Liberal Peace in Question. Politics of State and Market Reforms in Sri Lanka, London: Anthem. Forthcoming.

Rampton, D. and Welikala, A. (2005) The Politics of the South, Colombo: The Asia Foundation.

Richmond, Oliver P. 2007 The Transformation of Peace, New York: Palgrave Macmillan.

Riste, O. (2001) Norway's Foreign Relations - A History, Oslo: Universitetsforlaget.

Rottem, S. V. (2007) The Ambivalent Ally - Norway in the New Nato, Contemporary Security Policy 28(3): 619-638.

Rottem, S. V., G. Hønneland, et al. (2008) Småstat og energistormakt. Norges sikkerhetspolitiske rolle $i$ nord, Bergen, Norway: Fagbokforlaget.

Rupesinghe, K. (ed.) (2006) Negotiating Peace in Sri Lanka. Efforts, Failures and Lessons (Volume I and II), Colombo: The Foundation for Co-Existence. 
Said, E. W. (2001) The End of the Peace Process. Oslo and After, New York: Vintage.

Shanmugaratnam, N. and Stokke, K. (2008) 'Development as a Precursor to Conflict Resolution. A Critical Review of the Fifth Peace Process in Sri Lanka', In N. Shanmugaratnam (ed.), Between War and Peace in Sudan and Sri Lanka. Deprivation and Livelihood Revival. Oxford, UK: James Currey.

Sharma, S. D. (2009) China and India in the Age of Globalization, Cambridge: Cambridge University Press.

Skånland, Ø. H. (2008) "Norway is a Peace Nation." Discursive Preconditions for the Norwegian Peace Engagement Policy. Peace and Conflict Studies, Faculty of Social Science, University of Oslo.

Sriskandarajah, D. (2003) 'The Returns of Peace in Sri Lanka. The Development Cart before the Conflict Resolution Horse?', Journal of Peacebuilding and Development, 2.

Stokke, K. (2006) Building the Tamil Eelam State. Emerging State Institutions and Forms of Governance in LTTE-controlled Areas in Sri Lanka, Third World Quarterly 27(6): 1021-1040.

Stokke, K. (2007) 'War by Other Means: The LTTE's strategy of institutionalising power sharing in the context of transition from war to peace', Third World Quarterly 28(6): 1197-1201.

Stokke, K. (2011) 'Liberal Peace in Question: The Sri Lankan Case', In K. Stokke and

J. Uyangoda (eds.), Liberal Peace in Question. Politics of State and Market Reforms in Sri Lanka, London: Anthem. Forthcoming.

Stokke, K. and Uyangoda, J. (eds.) (2011) Liberal Peace in Question. Politics of State and Market Reforms in Sri Lanka, London: Anthem. Forthcoming.

Støre, J. G. (2008) Å gjøre en forskjell, Oslo: Cappelen Damm.

Sæther, E. (2008) The Conditional Autonomy of the Critical Press in China, University of Oslo, Department of Sociology and Human Geography.

Swamy, M. R. N. (1994) Tigers of Lanka. From boys to guerrillas, Colombo, Sri Lanka: Vijitha Yapa.

Tvedt, T. (2009) Utviklingshjelp, utenrikspolitikk og makt: den norske modellen ( $2^{\text {nd }}$ ed.), Oslo: Gyldendal akademisk.

Uyangoda, J. (2005) Conflict, Conflict Resolution and Peace Building, Colombo: University of Colombo, Department of Political Science and Public Policy.

Uyangoda, J. (2011) 'Travails of State Reform in the Context of Protracted Civil War in Sri Lanka', In K. Stokke and J. Uyangoda (eds.), Liberal Peace in Question. Politics of State and Market Reforms in Sri Lanka. London: Anthem. Forthcoming. 
Uyangoda, J. and Perera, M. (eds.) (2003) Sri Lanka's Peace Process 2002. Critical Perspectives, Colombo: Social Scientists' Association.

Uyangoda, J. and Gomez, M. (2007) State Reform in Sri Lanka: A Dialogue Series, Colombo: Social Scientists' Association.

Waltz, K. N. (1979) Theory of International Politics, New York: McGraw-Hill.

Wendt, A. (1999) Social Theory of International Politics, Cambridge: Cambridge University Press.

Wilson, A. J. (2000) Sri Lankan Tamil nationalism. Its origins and development in the $19^{\text {th }}$ and $20^{\text {th }}$ Centuries, New Delhi, India: Penguin.

Waage, H. H. (2004) "Peacemaking is a Risky Business": Norway's Role in the Peace Process in the Middle East, 1993-96. Oslo: International Peace Research Institute.

Zahran, G. and Ramos, L. (2010) 'From hegemony to soft power: implications of a conceptual change', In I. Parmar and M. Cox (eds.), Soft Power and US Foreign Policy. Theoretical, Historical and Contemporary Perspectives. London: Routledge.

Østerud, Ø. (2005) Introduction: The Peculiarities of Norway, West European Politics 28(4): 705-720.

Østerud, Ø. (2006) Lite land som humanitær stormakt, Nytt Norsk Tidsskrift 23(4): 303-316. 